\title{
Unionization and Job Satisfaction among Professional Library Employees in Academic Research Institutions
} Tina Maragou Hovekamp

\begin{abstract}
Previous research pertaining mostly to blue-collar unionized workers indicated that the reported job satisfaction among these employees tends to be lower than among nonunionized workers. The present study concentrated on a professional group - professional librarians in academic research institutions-to reexamine the issue. By comparing the survey results of union and nonunion participants, this research found that the presence of unions has a negative relationship with job satisfaction. However, the results of this study did not support the argument that such a relationship is a product of union culture, as some researchers have suggested. Salary was revealed as a more consistent predictor of job satisfaction. There was also the suggestion that part-time employment status might relate to the survey participants' happiness with their job.
\end{abstract}

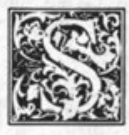

everal attempts to estimate the degree of job satisfaction among union workers have shown that this type of employee may report lower levels of satisfaction compared to nonunion workers. Research in this area has mainly concentrated on the blue-collar or nonprofessional worker. In addition, the few studies which have focused on professional employees have produced conflicting results, indicating that the relationship between unions and job satisfaction may be complex and not so predictable.

The present investigation was based on the survey results of a professional group of librarians in union and nonunion academic research institutions. The data received compared the reported levels of job satisfaction between the union and nonunion participants. To examine any possible association between union culture and the employees' attitudes, this research also explored the relationship between union membership and job satisfaction as well as the relationship between union loyalty and job satisfaction. The researcher believed that if unions had an impact, it would be particularly evident among registered union members or those most committed to their union.

The researcher analyzed the data using multiple regression. Several demographic variables which otherwise could affect the results of the research entered the regression equations as controls. This method also allowed the researcher to explore these variables and their possible relation to job satisfaction.

\section{THEORETICAL AND RESEARCH BACKGROUND}

Repeatedly dissatisfaction with employment conditions has been found as

Tina Maragou Hovekamp is Library Instruction and Public Services Librarian at the Leslie J. Savage Library, Western State College of Colorado, Gunnison, Colorado 81231. This article is based on the author's dissertation at the University of North Carolina at Chapel Hill. The completion of this research was made possible with the help of a CLR/Kellogg grant. 
a common explanation for the reason workers decide to unionize. As Charles Odewahn and M. Petty indicate, the literature for some time has supported the idea that economic and other job-related issues are a primary cause for union organizing. ${ }^{1}$

Researchers continue to reaffirm the link between job satisfaction and unionization. For example, Julius Getman, Stephen Goldberg, and Jeanne Herman found that voting behavior during union elections is affected by the level of employee satisfaction. ${ }^{2}$ They indicated that the less satisfied employees were more prone to vote for union representation than the more satisfied employees. In his study William Bigoness also found that there is a significant relationship between employee attitudes toward unionism and job satisfaction with respect to work, pay, supervision, and opportunities for advancement. ${ }^{3}$

Besides research findings on the relationship between job discontent and prounion behavior, a number of investigations have also shown that job satisfaction tends to be lower among union compared to nonunion employees after the establishment of bargaining relations. Both Richard Freeman and George Borjas were among the first to find that, on average, unionized workers report significantly lower levels of job satisfaction., ${ }^{4,5}$

Whereas Freeman and Borjas used a single item to measure overall job satisfaction, later studies explored the same issue in a more detailed way by examining the relation between union presence and different facets of job satisfaction. Thomas Kochan and David Helfman, for example, reported that unions have a positive effect on wages and this in turn has a significant, positive influence on the members' satisfaction with breadand-butter issues (pay, fringe benefits, and job security). ${ }^{6}$ However, when it came to satisfaction with other job issues such as job content, resource adequacy, and promotions, the researchers found a significant, negative relationship with union presence after controlling for wage level. Based on data compiled from a national probability sample of employed adults, Chris Berger, Craig Olson, and John Boudeau indicated that the relationship between union presence and different facets of job satisfaction might be indirect. ${ }^{7}$ Specifically, quite similarly to Kochan and Helfman, those researchers showed that unions are positively related to pay satisfaction because of higher pay rewards and pay values among workers. However, a negative relation was found between union presence and other job aspects, such as job content, supervision, or opportunities for promotion. The study tried to explain that such a negative relationship existed because of the employees' less favorable perceptions and lower values related to these issues. Berger et al. also indicated that when considering the overall job satisfaction, union workers tend to be less satisfied than workers in nonunionized environments.

\section{It is believed that in an effort to attract and maintain membership, unions emphasize the shortcomings of a work situation, which then acquire a greater importance for the employees.}

In 1987 Susan Schwochau again attempted to investigate the issue with data she collected from a national probability sample. ${ }^{8}$ Consistent with previous research, her analysis confirmed that union members report lower levels of job satisfaction than nonmembers in all job facets but pay. In a very similar study Ronald Meng found the same differences in job satisfaction among Canadian union and nonunion workers. ${ }^{9}$

In an effort to explain the above findings, researchers such as Russell Smith and Anne Hopkins argue that the politicization of the work force by the presence of the union is one possible cause of decreased job satisfaction..$^{10}$ It is believed that in an effort to attract and maintain membership, unions emphasize the shortcomings of a work situation, which then acquire a greater importance for the employees. 
Another frequently cited rationalization of the reasons why union workers report lower job satisfaction was discussed by Richard Freeman. ${ }^{11}$ According to his "exit-voice" concept, unionism creates mechanisms that enable workers to "voice," rather than suppress, their dissatisfaction. By doing this, members become more aware and more expressive of the possible problems associated with their jobs. It is for this very reason, Freeman says, that unionized employees respond more negatively to questions of job satisfaction than nonunionized employees. The advantage of this situation is that despite their dissatisfaction, employees have more opportunities actually to resolve problems in their employment relations. For instance, the grievance and arbitration system, or even the process of negotiations, allows employees to express openly their feelings and perhaps find a solution. In contrast, dissatisfied employees in nonunion facilities who do not suppress their emotions often view quitting their jobs as the only alternative.

Still, the relationship between unionization and job satisfaction is rather complex and still not fully understood. ${ }^{12}$ Furthermore, there have been findings from studies of unionized professional employees which contradict the idea of a negative relationship between unions and job satisfaction. For example, Luis GomezMejia and David Balkin studied the relationship between faculty organization and satisfaction with pay and other job dimensions. ${ }^{13}$ Their survey showed that union presence was associated positively with faculty pay satisfaction. In addition, they found no evidence of any association with satisfaction on issues such as promotion, supervision, job content, job context, or resource adequacy.

In a similar study of 260 Canadian university faculty, Bernadette Schell and Andrew Loed concluded that unionized faculty report the same high level of job satisfaction as nonunionized faculty. ${ }^{14}$ Furthermore, according to their analysis, "work itself was a major contributor to faculty members' satisfaction."15 Such results imply that the predictive rela- tionship between job satisfaction and unionism may not always be consistent. This may also mean that the relationship could be different for unionized professional employees as opposed to nonprofessional or blue-collar workers.

Michael Gordon, Laura Beauvais, and Robert Ladd confirmed this idea by finding that whereas job satisfaction was related significantly to union satisfaction and loyalty among a group of unionized technicians, these variables were hardly correlated in a sample of unionized engineers. ${ }^{16}$ The researcher speculated that "engineers [might] perceive their membership in the engineering profession, rather than in the union, as responsible for the rewards associated with their overall employment situation."17 The character of a professional occupation, in other words, might play an important role in the way individuals approach their job and what they expect to derive from it.

The present research concentrated on a particular professional group, professional library employees in academic research institutions. The researcher wanted to examine whether indeed these types of union employees have a different degree of job satisfaction than their nonunion colleagues.

Specifically, the hypotheses tested in this research examined differences in job satisfaction between professional librarians in unionized versus nonunionized institutions. Besides overall job satisfaction, this investigation looked at the relationship between unions and satisfaction separately with bread-and-butter, job content or growth, and work environment issues. To explore whether union culture may affect the way individuals perceive their jobs, this study also analyzed the variables of membership status and union loyalty as predictors of job satisfaction among unionized employees. The researcher believed that if unions related to job satisfaction, such an association could be best reflected in the sentiments of registered members or those most committed to their union.

The four hypotheses of this investigation explored the following research questions: 
- Is there a significant relationship between the presence of unions (unionization) and professional librarians' degree of overall job satisfaction?

- Is there a significant relationship between the presence of unions and professional librarians' satisfaction with bread and butter, job content or growth, and work environment issues?

- Is there a significant relationship between union membership status (whether an employee is a registered union member or a nonregistered union member) and professional librarians' job satisfaction?

- Is there a significant relationship between union commitment and professional librarians' job satisfaction?

\section{METHOD}

\section{Subjects and Setting of Study ${ }^{18}$}

The participants in the study were full-time or part-time employees with an M.L.S. or equivalent degree and professional appointments (academic or faculty) in academic research library institutions which were members of the American Research Library Association (ARL). The reason for selecting academic research libraries as the setting for this study was the relative availability of data on unionization among these institutions compared to smaller college libraries, as well as the fact that research libraries because of their complex, bureaucratic structure are more likely to be unionized than smaller libraries.

In August 1991 the researcher mailed requests for participation in the study to twenty-six research libraries in the United States, which at the time did not have union representation for either professional or paraprofessional staff. They selected these libraries by eliminating from a list of ARL academic libraries those which had union representation for professional and/or paraprofessional library staff. The final sample included twenty-six libraries drawn randomly from the remaining population.

Seventeen American research libraries which at the time had collective bargaining agreements for their professional library employees also received a similar mailing. Since most of the ARL libraries were not unionized, the sample of nonunion institutions was larger than that of union libraries. In this way the research samples represented more accurately the population of the study.

Library directors in both union and nonunion libraries received a letter describing the purpose of the study accompanied by a request for their institution's participation. As a result, nineteen nonunion (i.e., 73 percent of the originally selected nonunion libraries) and thirteen union libraries (i.e., 76 percent of the original number of unionized research libraries) agreed to participate in the study.

The reason for selecting academic research libraries as the setting for this study was the relative availability of data on unionization among these institutions compared to smaller college libraries, as well as the fact that research libraries because of their complex, bureaucratic structure are more likely to be unionized than smaller libraries.

Participating libraries provided lists of employee names. Using these lists and the percentages calculated for each institution, the researcher selected randomly two hundred individuals for each of the two groups of the study, union and nonunion. Law and health library professionals as well as librarians at regional campuses were not included in the samples. This exclusion was necessary because among the campuses, law, health, or regional campus libraries were not always part of the central research library system (in some cases they operated independently from it). In addition, since higher administrative staff (i.e., directors, assistant directors, and personnel administrators) are not represented by the union, this type of employee was not part of the union sample.

\section{Survey Instrument}

In order to measure employee job satisfaction, the researcher based questions, 
with a few modifications, on the short form of the Minnesota Satisfaction Questionnaire or MSQ.19 This questionnaire measured job satisfaction in regard to bread and butter, job content, or growth issues, as well as work environment.

The MSQ was appropriate to use in this study because it covered job facets relevant to the characteristics of the specific population and to the scope of this study. Moreover, previous tests on the reliability of the MSQ had already provided evidence that this instrument was quite reliable and consequently relatively safe to use. ${ }^{20}$ For each of the items in the job satisfaction questionnaire, researchers asked the subjects to respond using a 5-point Likert-type scale.

To explore the relationship between job satisfaction and union commitment, the survey also included eleven items adapted from Porter's Organizational Commitment Questionnaire (OCQ), which measured the union participants' loyalty to their bargaining association. Chester Schriesheim and Anne Tsui, Dan Dalton and William Todor, and Edward Conlon and Daniel Gallagher used a similar instrument in their previous union studies. ${ }^{21}$ This measure previously showed high levels of internal reliability and agreed with the definition of union commitment in the present study. The items of this measure were included only in the survey of the union sample. The response format for this measure also employed a 5-point Likert scale.

In addition to the survey items discussed above, those questionnaires sent to participants in the union sample asked them to identify whether or not they were registered union members. The survey instrument also requested that all respondents indicate their sex, age, total years of work as a library employee, employment status (full-time or part-time), and total annual salary. These variables were entered as "controls" in the data analysis. In this way it was also possible to explore any relationship these variables might have with job satisfaction.

The researcher collected most of the data for this study by the end of Decem- ber 1991. The response rate reached 91 percent including six (6) refusals to participate and thirteen (13) invalid responses. Within the nonunion group, 189 or 94.5 percent of the sample responded to the survey. From the union group, 174 or 87 percent returned responses.

\section{RESULTS}

Table 1 provides the population profile of this survey based on an analysis of the demographic characteristics of the respondents.

The results from table 1 show that the most distinct difference in the demographic characteristics of the nonunion versus the union group is in the area of salary, with the majority of union librarians placed in the upper salary scales. That might relate to the fact that within the nonunion group there was a larger percentage of younger and less experienced professionals. In addition, researchers observed that the distribution of the population regarding employment status (full-time versus part-time) was quite uneven for both groups. Despite that, it was the researcher's decision to include this control variable in the analysis of data.

The researcher also used regression analysis to test each of the four hypotheses. All regression equations included gender, age, years of library experience, employment status (full-time versus part-time), and salary as control variables. By including these variables, it was also possible to examine their contribution to job satisfaction.

The means of overall job satisfaction for the union and nonunion group were 3.555 and 3.687 , respectively, based on the Likert scale with 1 as the lowest value and 5 as the highest value. Consequently, the overall tone of the participants' feelings toward their job in both groups was somewhere between neutral and satisfied.

The regression analysis of the first hypothesis of the study revealed that union presence had a significant, negative relation to overall job satisfaction; the regression coefficient for the variable of union presence was equal to $-3.914, p<.01$. 
TABLE 1

SUMMARY OF DEMOGRAPHIC CHARACTERISTICS FOR RESPONDENTS

\begin{tabular}{|c|c|c|c|}
\hline $\begin{array}{l}\text { Demographic } \\
\text { Characteristics }\end{array}$ & $\begin{array}{c}\text { No. of Nonunion } \\
\text { Respondents }\end{array}$ & $\begin{array}{c}\% \text { of Union } \\
\text { Respondents }\end{array}$ & $\begin{array}{c}\% \text { of Total } \\
\text { Respondents }\end{array}$ \\
\hline \multicolumn{4}{|l|}{ Gender } \\
\hline Male & 34.8 & 38.0 & 36.3 \\
\hline Female & 65.2 & 62.0 & 63.7 \\
\hline \multicolumn{4}{|l|}{ Age } \\
\hline $20-30$ & 6.7 & 3.7 & 5.3 \\
\hline $31-40$ & 30.2 & 29.0 & 29.6 \\
\hline $41-50$ & 41.3 & 42.0 & 41.6 \\
\hline $51-60$ & 15.1 & 14.8 & 15.0 \\
\hline Over 61 & 6.7 & 10.5 & 8.5 \\
\hline \multicolumn{4}{|c|}{ Years of library experience } \\
\hline $1-5$ & 15.5 & 9.9 & 12.8 \\
\hline $6-10$ & 19.9 & 16.2 & 18.1 \\
\hline $11-15$ & 18.8 & 18.6 & 18.7 \\
\hline $16-20$ & 17.7 & 23.0 & 20.2 \\
\hline $21-25$ & 14.3 & 17.4 & 15.8 \\
\hline $26-30$ & 6.1 & 8.1 & 7.0 \\
\hline Over 31 & 7.7 & 6.8 & 7.4 \\
\hline \multicolumn{4}{|l|}{ Employment status } \\
\hline Full-time & 93.9 & 93.9 & 93.9 \\
\hline Part-time & 6.1 & 6.1 & 6.1 \\
\hline \multicolumn{4}{|l|}{ Annual salary } \\
\hline Less than $\$ 20,000$ & 4.5 & 1.8 & 3.2 \\
\hline$\$ 20,000$ to 24,999 & 10.6 & 3.7 & 7.3 \\
\hline 25,000 to 29,999 & 22.9 & 16.6 & 19.8 \\
\hline 30,000 to 34,999 & 21.2 & 13.4 & 17.5 \\
\hline 35,000 to 39,999 & 14.0 & 21.0 & 17.3 \\
\hline 40,000 to 44,999 & 14.5 & 20.2 & 17.3 \\
\hline Over $\$ 45,000$ & 12.3 & 23.3 & 17.6 \\
\hline
\end{tabular}

Additionally, among the demographic variables of this study, part-time employment and salary were also significant and related positively to overall job satisfaction; their regression coefficients were equal, respectively, to 12.232 and $2.331, p<.001$. The regression model for the determination of overall job satisfaction by union presence and demographic characteristics had a squared multiple correlation coefficient ( $R 2)$ equal to 0.086 $(p<.001)$; in other words, union presence along with the demographic control variables explained 8.6 percent of the variance of overall job satisfaction.

In addition to examining overall job satisfaction, this study took a more de- tailed look at the participants' satisfaction with several job aspects. To be more specific, the researcher divided participant responses to the 19-item job satisfaction questionnaire into three categories based on conceptual relationships among the questionnaire items. These included satisfaction with:

- Bread-and-butter issues (3 items). The job dimensions included in this category were: employee benefits, job security, and salary.

- Job content or growth issues (10 items). The job dimensions included in this category were: degree of job independence, variety of work, opportunity to render service, use of one's 
TABLE 2

REGRESSION COEFFICIENTS AND $t$ 's FOR THE DETERMINATION

OF DEGREE OF SATISFACTION WITH DIFFERENT JOB FACETS

UNDER UNION AND NONUNION CONDITIONS $(N=344)$

\begin{tabular}{lccc}
\hline Variables & Bread and Butter & Job Content/Growth & Work Environment \\
\hline Union & -0.026 & -2.408 & -1.717 \\
& $(-0.118)^{*}$ & $(-2.930)^{\ddagger}$ & $(-3.345)^{\ddagger}$ \\
\hline Gender & 0.160 & 0.054 & 0.116 \\
& $(0.709)$ & $(0.066)$ & $(0.225)$ \\
\hline Age & 0.019 & -0.119 & 0.203 \\
& $(0.120)$ & $(-0.206)$ & $(0.555)$ \\
\hline Years of library experience & -0.051 & -0.484 & -0.386 \\
& $(-0.513)$ & $(-1.313)$ & $(-1.669)$ \\
\hline Part-time versus full-time & 2.332 & 6.216 & 4.645 \\
& $(4.602)^{\ddagger}$ & $(3.373)^{\ddagger}$ & $(3.881)^{\ddagger}$ \\
\hline Salary & 0.533 & 1.451 & 0.524 \\
& $(6.321)^{\ddagger}$ & $(4.617)^{\ddagger}$ & $(2.744)^{\ddagger}$ \\
\hline$R^{2}$ & $0.158^{\ddagger}$ & $0.078^{\ddagger}$ & $0.072^{\ddagger}$ \\
Constant & 8.738 & 33.975 & 19.069 \\
\hline
\end{tabular}

${ }^{*} t$ 's appear in parentheses; ${ }^{\dagger} p<.01 ;{ }^{\ddagger} p<.001$

abilities, advancement opportunities, degree of job responsibility, opportunity for creativity, recognition received, feeling of achievement, opportunities for educational advancement.

- Work environment issues (6 items). The job dimensions included in this category were: social status in the campus community, decision-making competence of supervisor, relation of supervision to supervised employees, workplace policies, working conditions, relations among coworkers.

Table 2 presents the regression results of the analysis of job satisfaction with the above job facets by union presence and demographic characteristics.

The results of table 2 indicate that union presence has a statistically significant negative relationship with satisfaction in regards to issues of job content or growth $(p<.01)$ and work environment $(p<.001)$. On the other hand, the relationship between satisfaction with bread-and-butter issues and union presence was nonsignificant. Once again, among the control variables, part-time employment and salary turned out to be highly significant positive predictors of job satisfaction with all three job dimensions $(p<.001)$.

The third hypothesis of this study investigated the issue of job satisfaction within the union group. Specifically, it tested the significance of any possible differences between professional librarians who were registered union members at the time, and those who were not registered as official members but were covered by the bargaining agreement at their campus. The purpose of such an analysis was to determine whether union culture may affect the way registered members approach their jobs. Regression analysis showed that the variable of union membership was not a predictor of job satisfaction among unionized library employees; the regression coefficient for the variable of union membership was $2.264, p>.05$. The demographic variables, however, of part-time employment and salary level turned out to be fairly powerful predictors of job satisfaction among the union participants with regression coefficients respectively 
of $13.592, p<.01$ and $3.901, p<.001$. The $R 2(=0.196)$ of this regression model indicated that 19.6 percent of the variance of overall job satisfaction among unionized library employees was accounted for mainly by the variable of part-time status and salary regardless of union membership status.

The final hypothesis of this study explored the relationship between job satisfaction and union commitment. The researcher believed that those individuals most committed to their bargaining organization would reflect best the sentiments of the union group in this study. The results of the regression analysis indicated that the relationship between these two variables was nonsignificant. The regression coefficient for the independent variable of union commitment was 0.086, $p>.05$. As expected, part-time status and salary level were the only statistically significant variables in the regression equation for the prediction of overall job satisfaction $(p<.001)$.

\section{DISCUSSION}

Previous theoretical speculations and research findings tried to explain the influence of interest groups such as unions on their membership. Some theorists suggest that employee satisfaction is often affected by the unions' deliberate effort to stress the negative aspects of a workplace in order to attract and retain their membership. Other researchers propose that union mechanisms tend to generate a stronger expression of discontent among workers and, consequently, lower their reported level of job satisfaction. Past research concentrated mainly on blue-collar workers in an effort to investigate the relationship between unions and job satisfaction. The present study, however, looked at a specific professional group, professional librarians, in order to reexamine the issue.

Similar to previous findings, this study provides evidence that union presence is indeed a negative predictor of overall satisfaction among professional library employees. The data show that unionization along with demographic characteristics is a statistically significant, negative predictor of satisfaction, specifically with issues of job content or growth and work environment. To further explore the issue, the researcher tested the likelihood of a link between union membership status and job satisfaction; however, it was discovered that registered and nonregistered union members reported comparable levels of satisfaction. Similar results indicate that the relationship between union commitment and job satisfaction is also not significant. Union employees reported similar levels of job satisfaction regardless of their degree of union loyalty.

Based on the above findings, the researcher suggests that even though unionized professional librarians tend to report lower levels of job satisfaction than their nonunion colleagues, there is no clear evidence that such attitudes are a product of union culture. Neither the registered membership nor those most loyal to the union seem to have a stronger awareness or feelings of work injustice than nonregistered or less loyal union members. The mere presence of unions may encourage "exit-voice" behavior among union workers, as Freeman suggests; yet one might wonder whether job satisfaction is actually more strongly affected by other variables, typical of unionized environments but independent of union influences. ${ }^{22}$ For instance, it might be worth investigating whether the work environment in unionized workplaces is different than that in nonunion workplaces. According to the data of this study, unionized librarians report lower levels of satisfaction specifically with job content and growth and with work environment. The presence of a labor organization might imply a history of problems in the employeremployee relationship, and the case might be that these problems still persist and affect the employees' work experiences. In other words, union presence simply could be an indication, and not the actual source, of decreased levels of job satisfaction.

Further research needs to analyze in more detail the reasons why unionized 
library employees tend to be less content with their jobs than their nonunion colleagues. Why did the participants of this study indicate lower levels of satisfaction with job content and work environment issues? Are there problems characteristic of union workplaces and independent of union culture? Within the same framework, it would also be interesting to compare the levels of job satisfaction between unionized library professionals and unionized faculty on the same campuses.

A secondary finding of the present survey was that, contrary to previous research, unions did not seem to affect the way professional librarians felt about the extrinsic rewards of their jobs..$^{23}$ This possibly could imply either that collective bargaining did not improve the overall financial status of participants in the study or that those library professionals did not have any particularly favorable perceptions regarding the extrinsic rewards of their job.

Finally, among the demographic characteristics of this study, researchers consistently found salary and parttime employment status to be statistically significant, positive predictors of job satisfaction among the survey participants. The positive predictive relationship of salary with job satisfaction was not a surprise. Previous research findings focusing on the issue of pay have already shown that job satisfaction increases with salary. ${ }^{24}$ Part-time status, however, was a new significant variable in the determination of job satisfaction. This research suggested that among library research institutions, part-time employees tend to report higher levels of satisfaction with their job than full-time employees. Unfortunately, no conclusive inferences could be drawn in the present study since part-time employees were only 6.1 percent of the total survey population (see table 1). However, one may speculate that part-time employment could be a significant variable because of the importance it might carry among female-dominated professions such as the one involved in the present investigation (63.7 percent of the participants were females). Future studies should address the significance of this variable in connection to job satisfaction and examine whether this significance may relate to the characteristics of certain occupations.

\section{REFERENCES AND NOTES}

1. Charles A. Odewahn and M. M. Petty, "A Comparison of Levels of Job Satisfaction, Role Stress and Personal Competence between Union Members and Nonmembers," Academy of Management Journal 23 (Mar. 1980): 150-55.

2. Julius G. Getman, Stephen B. Goldberg, and Jeanne B. Herman, Union Representation Election: Law and Reality (New York: Russell Sage, 1976).

3. William J. Bigoness, "Correlates of Faculty Attitudes toward Collective Bargaining," Journal of Applied Psychology 63 (Apr. 1978): 228-33.

4. Richard Freeman, "Job Satisfaction as an Economic Variable," American Economic Association 68 (May 1978): 135-41.

5. George Borjas, "Job Satisfaction, Wages, and Unions," Journal of Human Resources 14 (Winter 1979): 21-40.

6. Thomas Kochan and David E. Helfman, "The Effects of Collective Bargaining on Economic and Behavioral Job Outcomes," in Research in Labor Economics, ed. R. G. Ehrenberg, vol. 4 (Greenwich, Conn.: JAI Pr., 1981).

7. Chris J. Berger, Craig A. Olson, and John W. Boudeau, "Effects of Unions on Job Satisfaction: The Role of Work-Related Values and Perceived Rewards," Organizational Behavior and Human Performance 32 (Dec. 1983): 289-324.

8. Susan Schwochau, "Union Effects on Job Attitudes," Industrial and Labor Review 40 (Jan. 1987): 209-24.

9. Ronald Meng, "The Relationship between Unions and Job Satisfaction," Applied Economics 22 (Dec. 1990): 1635-48. 
10. Russell L. Smith and Anne H. Hopkins, "Public Employee Attitudes toward Unions," Industrial and Labor Relations Review 32 (July 1979): 484-95.

11. Richard B. Freeman, "The Exit-Voice Trade-off in the Labor Market: Unionism, Job Tenure, Quits, and Separations," Quarterly Journal of Economics 94 (June 1980): 643-74.

12. Schwochau, "Union Effects," 209.

13. Luis R. Gomez-Mejia and David B. Balkin, "Faculty Satisfaction with Pay and Other Job Dimensions under Union and Nonunion Conditions," Academy of Management Journal 27 (Sept. 1984): 591-602.

14. Bernadette H. Schell and Andrew S. Loeb, "An Investigation of General Happiness Level, Collective Bargaining Attitudes, Job Satisfaction, and University and Union Commitment of Faculty Members in Canada," Journal of Social Behavior and Personality 1 (Oct. 1986): 537-56.

15. Ibid, 548 .

16. Michael E. Gordon, Laura L. Beauvais, and Robert T. Ladd, "The Job Satisfaction and Union Commitment of Unionized Engineers," Industrial and Labor Relations Review 37 (Apr. 1984): 359-70.

17. Ibid, 365 .

18. For a detailed description of the design of this study see Tina Maragou Hovekamp, "Unions and Work Attitudes: Job Satisfaction, Work Values, and Organizational Commitment of Professional Librarians" (Ph.D. diss., Univ. of North Carolina at Chapel Hill, 1993), 75-79.

19. David J. Weiss, Rene V. Dawis, George W. England, and Lloyd H. Lofquist, Manual for the Minnesota Satisfaction Questionnaire (Minneapolis: Univ. of Minnesota, Industrial Relations, 1967).

20. For more details, see ibid, 23-26.

21. Chester A. Schriesheim and Anne S. Tsui, "Dual Commitment to Company and Unions" (Paper presented at the annual meeting of the Academy of Management, Detroit, 1980); ibid., "Measures of Attitudes toward Company and Union: Development and Application" (Paper presented at the annual meeting of the American Institute of Decision Science, Las Vegas, 1980); Dan R. Dalton and William D. Todor, "Antecedents of Grievance Filing Behavior," Academy of Management Journal 25 (Mar. 1982): 158-69; Edward J. Conlon and Daniel J. Gallagher, "Commitment to Employer and Union: Effects of Membership Status," Academy of Management Journal 30 (Mar. 1987): 151-62.

22. Freeman, "The Exit-Voice Trade-off."

23. Kochan and Helfman, "The Effects of Collective Bargaining"; Berger and others, "Effects of Unions on Job Satisfaction; Gomez-Mejia and Balkin, "Faculty Satisfaction"; and Schwochau, "Union Effects."

24. Gomez-Mejia and Balkin, "Faculty Satisfaction," 598. 


\section{An invaluable resource!}

\section{from the Association of College \& Research Libraries}

\section{Vocational Technical Resources for Community College Libraries}

Mary Ann Laun, editor

The most comprehensive and current compilation of annotated bibliographies covering both print and nonprint resources needed to support vocational and technical curricula for community college or vocational/ technical institutions. A total of 58 career fields organized into ten discipline areas:

- Allied Health

- Building and

Construction Trades

- Business

- Communications/Production Technologies

- Criminal Justice and Law
- Education

- Engineering and

- Graphic and Technology

- Sciences Apparel Arts

- Social Services

Each career field begins with an Introduction describing the nature of the work involved, required skills, educational background, and trends in the field. Pertinent associations, accrediting/certifying bodies, and selected trade and professional journals for each area of study are listed. Name, title, and journal indexes are included for easy cross-reference.

Essential to undergraduates, vocational and technical students, librarians, faculty, and the general public looking for information on vocational resources.

$\$ 95.00$, ACRL members $\$ 85.00$

ISBN 0-8389-7775-8, 622p., 1995

\section{Order from:}

ACRL

Attn: Hugh Thompson

50 East Huron St.

Chicago, IL 60611
For faster, more personal service: call (800) 545-2433, press 7 or

Fax (312) 836-9958 